\title{
Operation Department: Infection Control
}

\begin{abstract}
Infection control in the operation department is the result of many single factors and routines, based on experience, documentation and expert panels through more than a hundred years. Many factors and routines in surgery are evidencebased, but most of them are still lacking evidence and can probably never be investigated because of ethical problems. Consequently, consensus and guidance are used to a great extent. Surgery opens into sterile tissues for hours, where there is massive tissue damage by knife, diathermy, clogging of vessels, pressure against and drying of tissues, decreased blood supply, impaired phagocytosis and impaired infection defence. Microbes deposited in this devitalized tissues may find a good basis for growth and proliferation if there is lack of infection control and sterility. For patients with ongoing infections and who need surgery, special routines are made to prevent the spread of infections in the operation department. This chapter is a practical description of many important preventive procedures that may protect the surgical patient against surgical site infection (SSI).
\end{abstract}

\section{Keywords}

Surgical site infection - SSI - Postoperative wound infection · Organization and function · Personal hygiene $\cdot$ Scrub suits $\cdot$ Operation team $\cdot$ Sterility $\cdot$ Microbes Ventilation and air pressure - Clearing and preparation of operating rooms Cleaning and disinfection of rooms · Disinfection of equipment and instruments, Preoperative routines - Sluice functions - Postoperative phase Patients with infections $\cdot$ Surgery on pulmonary tuberculosis 


\subsection{Purpose}

- Prevent postoperative infection.

- Prevent infection transmission from patients being operated to staff, instruments, equipment and environment.

\subsection{Comprise}

- All personnel including students, visitors, temporary staff, hospice aide, supervisor, service personnel, etc., as well as equipment, instruments and environment associated with the operation department. All patients and their beds and equipment brought in and out of the department.

- Anyone involved in surgery (contact with wound surfaces and tissues) and/or in direct contact with sterile equipment used invasively or on usually "sterile" mucous membranes.

\subsection{Responsibility}

The hospital management should ensure surgical activities are in accordance with the quality standards of hygiene and infection control for patients and personnel and ensure that patients with infections or susceptible to infections get adjusted surgery and are protected against the spread of infection. Postoperative infections must be registered, assessed and followed up.

The department management should promote hygiene principles and ensure safe conditions during surgery for the patient and personnel concerning quality, safety, environment, functional conditions and resources.

Each employee shall comply with the department's hygiene guidelines, infection control measures and personal hygiene.

\subsection{Practical Measures}

Infection control in the operation department is the result of many single factors and routines, based on experience, documentation and expert panels through more than a hundred years [1-13]. Many factors and routines in surgery are evidence-based, but most of them are still lacking evidence and can probably never be investigated. Consequently, consensus and guidance are used to a great extent.

Access control is a specific restriction for the surgical department to prevent transmission of infection. This control applies to patients, personnel, visitors, equipment and instruments. 


\subsubsection{Personal Infection Protection}

- The department is a green and clean area. The uniforms are quickly burdened with bacteria [14]. Therefore, replace the uniform/private clothes with the surgical department's green uniform and shoes before entering the department. Use cap that covers the hair and ears, and wash the hands before entering the department.

- Hand hygiene and gloves. See Chap. 12 on hand hygiene and wearing gloves.

- Jewellery (rings, bracelets, necklaces, earrings, etc.), watches or piercing is not allowed in the operation department or with other patient-associated work.

- Private clothing is not allowed except for underwear. No private textiles will be used as headgear.

- All equipment brought into the department should be disinfected. Minimum personal equipment should be brought in. Disinfect mobile phones, searchers, pens, glasses, ID badges, etc. before bringing in. Use cloths with alcohol. ID signs and access cards may be heavily contaminated with microbes [15].

\subsubsection{Blood-Borne Infections and Other Infections}

In the operation department, the personnel may be exposed to infection from patients, or they may themselves become a source of infection with the risk of transmission to equipment, colleagues and patients $[11,16,17]$.

- Avoid accidents like stabbing and cutting damage; wear double gloves for bloodborne infection and invasive procedures.

- Use surgical mask/cap and optionally visor/goggles during invasive procedures.

- Immediate measures: follow advice and measures if accident. See chapter on: "Accidents with blood- or tissue".

- Hepatitis B vaccine should be offered to all employees. Inform all newcomers. See also chapter on "Infection Control for Health Professionals".

- Ongoing infection or carrier status. Individuals with acute infectious or carrier state of defined blood-borne viruses (hepatitis A, B, C, D and E, HIV, HTLV, etc.) should not participate in invasive treatment. The same applies to carriers of group A streptococcal infection, MRSA, VRE and other multidrug-resistant bacteria (MDRO). See chapter "Infection Control for Health Professionals".

- Tracing of infections among personnel. In case of MRSA infection transmitted to a patient, exposed personnel should be tested (see MRSA procedures). If there are two or more SSIs with group A streptococci, the operating team and other personnel present during the operations are tested for carrier status [16]. After infection from patient to personnel, it may be appropriate to test those who have been in contact with the patient [17]. 


\subsubsection{Protective Clothing}

The operation department is a "green and clean zone". In this area, only clean green clothes (or selected colour) and clean socks, shoes and caps are put on before entering. Private clothes or shoes increase the burden of particles and microbes in the environment and are not allowed. Follow the routines and change to clean scrub suits every day and after visiting other departments, after taking part in a contagious operation and after contamination of the scrub suit. No green clothes outside the operation department! Exceptions are urgent activity or transfer of the operated patient to postoperative/intensive departments. During transfer, change shoes and use a clean white gown (changed after each shift or more often) over the scrub suit, and immediately return to the operation department. After working in scrub suit outside the department, change to a new green scrub suit upon return.

- Surgical masks for everyone in the operating room. The coloured side should be out, white side in. Bend the clamp to fit it over the nose. Tie up on the head outside the cap and down the neck. Take off the mask by first opening it in the neck and then on the head to avoid that it falls down the chest. Do not reuse the mask!

- Respiratory protection (filtering half masks) without exhalation valve-P3 mask -is used for operations with suspected airborne infection (see "isolation regimes" and "respirators"). Learn to take on and off the respirator.

- Visor/goggles are used during surgery where one knows there is a risk of splashing. Blood-borne virus may penetrate normal eye mucosa.

- Sterile surgical gown should be used by all working in the surgical area and/or with sterile instruments. During operations with larger amounts of blood/body fluids, the gown should have fluid-tight front and sleeves.

- Sterile gloves should cover well the cuff of the operating gown. Surgical hand disinfection (see separate section). Gloves have often holes, most commonly observed when removing the gloves. Use quality gloves that can withstand pressure and pull, etc., and wash the hands after wearing gloves.

\subsubsection{Other Infection Control Measures}

- Covering. Surfaces/areas that are expected to be contaminated with blood/body fluids are covered/shielded with liquid-proof material.

- Compresses are control-counted. Compresses should have high quality and should not release loose particles. Deposit of particles and debris in the wound poses a risk for SSI when establishing locus minoris resistentiae - a site for bacterial growth and infection.

- Used instruments are opened and brought quickly to cleaning and disinfection in instrument washer. Avoid drying of instruments due to the risk of prions.

- Manual cleaning of equipment and instruments before disinfection is not recommended. If such a procedure is to be carried out, for example, for air-powered tools, optical equipment, etc., special protective conditions should be available, and the process should take place under the fluid level to avoid splash. 


\subsubsection{Localities}

See also Chap. 33 on "Prevention of Postoperative Wound Infections."

The operation department is centrally located, easily accessible from intensive units and emergency services and shielded from transit traffic.

- Green zone with a high level of infection control is clearly defined with the best practices followed by the patients and staff.

- Patient waiting area should be in the green zone. Surgical personnel in scrub suits serve the patients. There is no access or transit traffic for other personnel.

- Sluice systems for patients and staff.

- Patient sluice for bed, stretcher and 2-3 persons (from 16 to $18 \mathrm{~m}^{2}$ ) for any pretreatment of the patient. Wash the basin and waste bin, but not the storage space.

- Staff sluice with space adapted to the number of employees, visitors, students, etc. (1-2 $\mathrm{m}^{2}$ per person). Ample wardroom for dressing and with separate closets for private clothes, toilet, shower, cloth racks for used laundry and sink. From the wardrobe walk through a smaller sluice where cap and shoes (preferably washable) are put on, and hand hygiene is done before entering the department.

- A separate textile storage room for green cloths (scrub suits, etc.) in connection to the wardrobe.

- Storage rooms for operation tops (operating table) and one separate storage for clean cover material on the top. Cover the operation top with single-use plastic after cleaning and preparing for the next patient.

- Washing room for operation tops: unclean and clean sides with separate exhaust air and sluice to avoid the spread of aerosols into the operation corridor.

- Shoe washing machine for washing and drying, unclean and clean sides with separate exhaust air and sluice to avoid the spread of aerosols into the operation corridor.

- Surgical hand disinfection room: 3-6 $\mathrm{m}^{2}$ depending on the staff number, with shielded basin area to avoid splashes. Written guidance, only current disinfectants and soaps and clock are on the wall. No storage space due to aerosols - and no other functions. See Chap. 34, surgical hand disinfection.

- Anaesthesia induction room with ample space for patient bed and 2-3 people (ca. $16 \mathrm{~m}^{2}$ ). Wash basin and cabinets for clean equipment used in connection with induction.

- Operating theatre: good space for a minimum of five to eight people, patient and equipment. Necessary area is $40-60 \mathrm{~m}^{2}$. Storage of equipment in the theatre is not recommended. If still extra equipment is needed to be stored, place it in tight, clean boxes, cleaned outside between operations. Coordinating staff assisting the operation team must have at least $2 \mathrm{~m}$ distance from the patient and sterile equipment, in all directions. Walls, floors and ceilings should be complete and well maintained, and the surfaces must withstand strong disinfectants. There should be zero tolerance for wires and hoses on the floor. 
- Storage rooms and hygienic requirements for storage of sterile equipment. Clean/ sterile equipment should be cleaned on the outside of the packages and stored in cabinets with glass doors to protect against dust. Storage rooms for sterile equipment should not be used as office, meeting room, storage room for unclean items, etc.

- Sterile storage room: plenty of space (16-20 $\left.\mathrm{m}^{2}\right)$, dependent on activity, easy to clean, and a wash basin/dispenser for hand disinfection in close proximity-outside the door. Cabinets with glass doors. Cleaned daily and the surface of the benches is disinfected. Limited access due to burden of microbes and particles in the air. See "Guidelines for Storing Clean and Sterile Equipment".

- Sterile storage room for anaesthesia: 14-18 $\mathrm{m}^{2}$, follow the guidelines described above.

- Sterile fluid storage room should be in a separate compartment: 4-6 $\mathrm{m}^{2}$, follow the guidelines described above.

- Storage for clean equipment, couch equipment (to place and adjust the patient on the operation table), etc. is surveyable, 16-20 $\mathrm{m}^{2}$ and easy to clean, and the floor should only be used as storage space for equipment to be run on wheels/ pulleys. Cabinets with glass doors to protect against dust. Couch equipment must undergo thorough disinfection after each use and must be stored clean or may be disposable.

- Storage of “clean-unclean" equipment. A designated storage room (16$20 \mathrm{~m}^{2}$ ) for equipment and machines containing water, like water heater equipment, that cannot be disinfected satisfactorily after use. This equipment is constantly exposed to the growth of bacteria in the inner parts. If the cleaning process is unsatisfactory, it should be washed and disinfected thoroughly outside and stored separately. Connectors to the machines should be considered as potential sources of infection for gram-negative bacteria and mycobacteria.

- Storage of mechanical equipment (CPAP, ventilators etc) with internal technical/electric parts that are air-cooled by drawing air from the room, should be evaluated for special handling and storage since the contamination of inner parts may be a risk for patients.

- Storage for plaster and equipment for plastering should be a separate, clean and dry room, not stored with other equipment. Plaster is a good growth material for microbes, and it is mostly not sterile. Plaster should be placed in clean, dry cabinets with glass doors to protect against dust and microbes.

- Disinfection room $\left(16-20 \mathrm{~m}^{2}\right)$ is divided into a clean and unclean side. This room is a "wet room" that should have negative air pressure towards corridors and operating rooms. The decontaminator and instrument washing machine, etc. should be checked daily for temperature and logged at regular intervals. The floor should not be used as storage space and should be easy to clean.

- A well-designed disinfection room for anaesthesia equipment $\left(16 \mathrm{~m}^{2}\right)$ is needed. 
- Sterilization central for disinfecting, controlling, packing, sterilizing and storing of sterile items is often placed nearby or in connection with the operation department, with a separate sluice for changing clothes. The central may also be outside the operating area, with a clean and direct transport path (elevator, trolleys, etc.) to the operation department. A separate room for washing and drying of the transport trolleys between each use is needed.

- Inspection/disinfection. All disinfected and cleaned equipment, ultrasonic bath, instrument washing machine, etc. are checked during the process. A workplace and place for necessary equipment require approximately $10 \mathrm{~m}^{2}$.

- Packing room-packing of clean equipment to be sterilized. This clean room area is dependent on the operative activity of the hospital and the number of employees. The room should be at least $16 \mathrm{~m}^{2}$ and $7-10 \mathrm{~m}^{2}$ per workplace. Positive air pressure with filtered air in, as well as more than 15 air changes per hour.

- Autoclave room-sterilization room with a sluice system. The area is dependent on the number of autoclaves, sizes and types. Through-fare autoclave is an advantage with one unclean input side and one clean side for out take. A separate steam exhaust ventilation and negative air pressure on the unclean side are needed. The central should be shielded from noise, heat and steam from this unit to avoid humidity on prepared sterile instrument packs. A regular control of autoclave and other sterilization machines is needed.

- Storage for sterile equipment. The same quality as on sterile stock in the operation department.

- Unpacking of goods that have outer packaging is done in a separate room with a sluice to the sterile central. The room should have a negative air pressure and exhaust ventilation.

- Other storage needs are determined by the sterile and operation department's activities.

- Other rooms are waste disposal room (12-16 $\mathrm{m}^{2}$, with negative air pressure and wash basin); textile room; toilet and shower (minimum one per ten employees); dining, rest and meeting rooms; and general office.

\subsubsection{Bacteria, Ventilation, Humidity and Temperature}

The number of airborne particles and bacteria in the operating theatre should be very low. There are specific requirements concerning colony-forming units (CFU) per $\mathrm{m}^{3}$ of air $[6,11-13,18-23]$. All equipment brought into this room should be clean and have a low bacterial burden. See also chapter "Prevention of Postoperative Wound Infections, Point D".

- Uncontrolled air currents may occur from sudden and large movements in the room and increase the risk of bringing particles and microbes from the staff and environment to the sterile area and to the surgical site. Traffic in and out of the operating room creates uncontrollable air currents [3, 4, 12, 13, 18-23]. 
- Tranquillity and close the doors before the start of surgery for to settle airborne bacteria-carrying particles.

- Persons present in the operating room have an impact on the number of bacteriacarrying particles in the air [12]. Ideally, no more than eight persons should be present in a regular operating room. Local routines should be followed.

- Clothing reduces bacteria release from the skin into the air. Covering all the skin and using dense textiles reduce the release of skin cells, particles and bacteria even more.

- Instruments should be covered immediately after laying-until use. Check air currents. Avoid contamination of sterile instruments from persons that unaware come into the airflow that goes towards the instrument tables.

- Ventilation is $15-25$ air changes/h. $\mathrm{CO}_{2}$ level is $<1000 \mathrm{ppm}$. Fresh air supply (filtered air) is minimum of $15 \mathrm{~L} / \mathrm{s} /$ person $+2 \mathrm{~L} / \mathrm{s} / \mathrm{m}^{2}$ surface in the operating room.

- Positive air pressure in operating rooms and sterile storage rooms in relation to the rest of the department.

- Sterile storage room is 10-17 air changes/h.

- Humidity is $35-40 \%$ in operating rooms. High moisture may increase bacterial growth, however weighted against a comfortable working environment. Humidity is $35-60 \%$ in sterile store rooms.

- Temperature is $18-25^{\circ} \mathrm{C}$. Higher temperatures can increase the growth of bacteria/release from the skin. Do not use fancoil or refrigerators. Condensation and dust collection lead to growth of bacteria and fungi in the exhaust air.

- LAF ceiling should be regularly checked by special procedures.

Bacterial load of the air is defined in colony-forming units $(\mathrm{CFU}) / \mathrm{m}^{3}$ air The following is recommended [6, 9, 11, 20-23]

\begin{tabular}{l|l}
\hline Operating room, common & $<100 \mathrm{CFU} / \mathrm{m}^{3}$ \\
\hline Operating room, ultraclean (LAF) & $<10 \mathrm{CFU} / \mathrm{m}^{3}$ \\
\hline Invasive investigations/laboratory operations & $<100 \mathrm{CFU} / \mathrm{m}^{3}$ \\
\hline Sterile storage/packing room & $<150 \mathrm{CFU} / \mathrm{m}^{3}$ \\
\hline
\end{tabular}

CFU controls of clean rooms are done in defined systems where air samples are taken in a sterile method several times, before, during and at the end of surgical treatment. Air is fed quickly through a calibrated system, and bacteria are deposited directly on a growth medium. This is incubated in a culture system for 2-7 days, and the number of colony-forming bacteria is counted. Fungi are also noted. The presence of fungi in clean rooms is not in accordance with clean room work. (See chapter "Prevention of Postoperative Wound Infections", point D for the performance of CFU control.) Measurements show that most bacteria in the air come from persons present in these clean rooms.

- Airborne infection-ventilation system. Patients with airborne infections should be treated in the operation department, if needed. This may be done without transmission of contaminated airborne dust particles, aerosols or droplets to 
other parts of the department and ventilation ducts $[6,11]$. The ventilation ducts of the actual operating room should be closed (and taped over) towards adjacent rooms and exhaust ducts (if the ducts are common with other operating rooms) $[6,11]$. A negative air pressure $(-25 \mathrm{~Pa})$ can be established in the operating room and also later on used for airborne infections in the event of risk of aerosols, particles or droplets of infectious material. Negative pressure condition must be kept constant. "Reversible" pressure ratio rooms, used both as positive-pressure and negative-pressure room, can create uncertainty with regard to contamination within air ducts and filters, if not followed up [24, 25]. Operating rooms with LAF system should not be used for patients with infections. See Sect. 35.10.

\subsubsection{Cleaning}

Thorough cleaning between operations, final cleaning in the end of the day and disinfection and control in the morning, before the operations, are the basic requirements for all types of operating rooms in order to maintain "clean room standard" [19-23].

Cleaning products (soap and detergents) should be the same ordinary as used in the rest of the hospital and should satisfy safety requirements, including being free of microbial growth (see chapter "Cleaning of Rooms"). For cleaning at surgery departments, specially trained personnel are required.

\subsubsection{Cleaning Equipment}

- Cloths and mops must meet the quality requirements for release of particles and purity. Follow guidelines for handling used textiles.

- Clean equipment is used for each room.

- The mopstick is cleaned manually, and the bucket is disinfected in the decontaminator.

- Clean the cart and rack daily with soap and water.

\subsubsection{Cleaning Frequency}

\section{Main Cleaning Two Times per Year}

- Sluice systems for patients and personnel, operating rooms, anaesthesia induction rooms and surgical hand disinfection room.

- Windows.

\section{Main Cleaning One Time per Year}

- Storage rooms for clean and sterile equipment.

- Operation department - the rest of the rooms.

\section{LAF System}

- Splash and contamination must be removed after each surgery.

- Cleaned once per year with subsequent particle/air velocity check performed by a specialist (Table 35.1). 
Table 35.1 Other regular cleaning

\begin{tabular}{l|l}
\hline Other regular cleaning & Frequency \\
\hline Wall, operating room & Daily/final cleaning \\
\hline Suspension of operating lights & Weekly wash at the height $(180 \mathrm{~cm})$ \\
\hline Suspension for surgeon pendulum & Daily + needs \\
\hline Anaesthesia pendulum & Daily + needs \\
\hline Ventilation valves & Daily + needs \\
\hline Cooling unit/of unit & Weekly (daily at the operating rooms $)$ \\
\hline & In accordance with instructions for use \\
\hline Drying cabinet & $\begin{array}{l}\text { NB! May be contaminated by bacteria and } \\
\text { fungi. Avoid using it. If used, clean the outside } \\
\text { daily }\end{array}$ \\
\hline Extractor fans & Weekly + daily at the bottom \\
\hline Trolleys, instrument boards, carts, etc. & Weekly to monthly \\
\hline
\end{tabular}

\section{Operation Top, Table and Shelf}

\begin{tabular}{|c|c|}
\hline 1. Operation table top/table & Cleaned in the laundry after use \\
\hline & $\begin{array}{l}\text { When infected during surgery, disinfect the } \\
\text { table top/table in the operating room, and } \\
\text { follow the procedures for disinfection time } \\
\text { before it is brought to the laundry room }\end{array}$ \\
\hline 2. Operation department without laundry & Clean or disinfect in the operating room \\
\hline 3. Plinth (base) for operating table & Cleaned according to guidelines \\
\hline 4. Extra cleaning of operating table/top & Weekly and when needed \\
\hline Patient lift & Cleaned after use and weekly \\
\hline Unit for single-use heater & $\begin{array}{l}\text { Washed after use. The connection hose is } \\
\text { cleaned in the washing machine if required }\end{array}$ \\
\hline Anaesthetic waggon, trolley & See separate procedures \\
\hline Anaesthetic apparatus, monitoring equipment & See separate procedures \\
\hline Blood pack cabinet, heating cabinet & Weekly + when needed \\
\hline Refrigerator/freezer & Every month/half year + if needed \\
\hline Sterile storage rooms & $\begin{array}{l}\text { Daily cleaning of floors and horizontal } \\
\text { surfaces and monthly cleaning of shelves and } \\
\text { inside of cabinets }\end{array}$ \\
\hline Sterile storage room-Remote & Cleaning every 14 days \\
\hline \multirow[t]{3}{*}{ Medicine room } & Daily, clean the floor, sink and bench \\
\hline & $\begin{array}{l}\text { Monthly, cleaned drawers, medicine shelves, } \\
\text { cabinets and refrigerators }\end{array}$ \\
\hline & C-bench, for preparing medicines \\
\hline \multirow[t]{2}{*}{ Other warehouses and clean rooms } & $\begin{array}{l}\text { Daily cleaning of floors and horizontal } \\
\text { surfaces }\end{array}$ \\
\hline & Quarterly cleaning of cabinets and drawers \\
\hline $\begin{array}{l}\text { Sluices, handwashing room, disinfection } \\
\text { room }\end{array}$ & $\begin{array}{l}\text { Daily cleaning of floor and horizontal } \\
\text { surfaces } \times 2+\text { if required }\end{array}$ \\
\hline
\end{tabular}




\begin{tabular}{l|l}
\hline Anaesthesia induction room & $\begin{array}{l}\text { Floor and horizontal surfaces are cleaned } \\
2 \times \text { daily }+ \text { if necessary }\end{array}$ \\
\hline Preparation room (tissue samples) & $\begin{array}{l}\text { Monthly cleaning of cabinets and drawers } \\
\text { Daily cleaning of floor and horizontal } \\
\text { surfaces }+ \text { if necessary }\end{array}$ \\
\hline & Monthly cleaning of cabinets \\
\hline Corridor & The floor is cleaned 3 $\times$ daily \\
\hline Green elevator & Daily \\
\hline Personnel rooms, wardrobes & Daily \\
\hline
\end{tabular}

\subsubsection{Clearing and Preparation Before and After Surgery}

\subsubsection{Before Surgery}

Operating room—morning: Operating lights, operating tables, technical equipment and all horizontal surfaces at work height are wiped off by $70 \%$ alcoholic disinfectant. Floor is moist-mopped [22].

Anaesthesia induction room-morning: Lamps and surfaces are wiped off with $70 \%$ alcoholic disinfectant. Floor is moist-mopped.

\subsubsection{After Each Operation}

\section{Cleaning and Preparation of the Operating Room After Each Operation [22]}

Surgical nurse clears the operating room for instruments, sterile and used equipment.

Anaesthesia personnel takes care of own equipment.

Used textiles: Check and remove all from the room. Sort, i.e. wet/bloody textiles are packed in plastic bag before it is put in the textile bag; other textiles are placed unpacked in a textile bag that closes.

\subsubsection{Waste}

- Black bag: household waste and relatively little contaminated and moist waste.

- Yellow bag in risk box/box: wet through blood compresses, blood clots, drainage bottles that cannot be emptied into decontaminator, etc.

- Plastic cans/boxes: stinging/cutting waste.

- Waste buckets: cleaned/disinfected in flush decontaminator.

\subsubsection{Suction Flasks, Etc.}

- Drained, cleaned and disinfected in a flush decontaminator or emptied into a flush decontaminator and then cleaned/disinfected in an instrument washing machine.

- Accessories for suction flasks are cleaned and disinfected in the instrument washing machine optionally in a flush decontamination unit.

- Stand/holder for suction flasks. Manual cleaning.

- Suction ejector: follow local guidelines. 


\subsubsection{Cleaning and Disinfection}

- Fixtures, technical equipment, operation lamps, etc. are cleaned with detergent and water.

- Walls: wash where there have been spills/splashes.

- Floors are wet-mopped.

- Operation lamps, instrument tables, etc. are wiped over with $70 \%$ alcoholic disinfectant.

The operating room is made ready for the next operation.

\subsubsection{Operation of Infected Patient}

Infection risk is considered before the surgical treatment and re-evaluated during operation.

Measures are depending on the degree of infection risk: larger and less risk of transmission.

Extreme dangerous infections, like Ebola, Lassa, SARS, MERS, Nipah, etc., are treated in a separate risk level 4 units.

\subsubsection{Selection of Operating Rooms and Time}

- Do not use LAF operating rooms for known infections, regardless of infection.

- Plan the infection operation at the end of the day, as assessed from the patient's condition and type of infection.

- Minimum equipment present in the operating room.

- Negative pressure is an advantage in terms of infections spread through air.

- Airborne contamination: choose an operating room with separate ventilation or ventilation that can be shut off and close to and from ventilation ducts with plastic and tape.

\subsubsection{High Risk of Infection and Transmission (by Question, Contact Infection Control Personnel)}

- Infected tissue with necrosis.

- Draining of pus cavities, abscesses, etc.

- Large, massive skin infections.

- Patients exposed to or colonized with or ongoing infection with multiresistant bacteria such as methicillin-resistant Staphylococcus aureus (MRSA) or other multidrug-resistant organisms (MDRO).

- Patients in contact with the health service abroad last year, where no microbiological survey has been made afterwards.

- Patient with blood-borne infection (HIV, hepatitis viruses, prions).

- Patient with bacterial or viral gastroenteritis.

- Patient with respiratory infection (influenza, tuberculosis, other airborne infections). 


\section{Preparation}

Clean/cover. The operating room is cleared for unnecessary equipment, and fixed equipment is covered. Consider the use of complicated technical equipment that is difficult to clean/disinfect.

Ventilation: check for control of contaminated air.

Disposable equipment is preferably used if disinfection must be carried out chemically or when disinfection procedure is difficult to perform. Do not take in more equipment than necessary.

Collecting packaging: It should be enough for infectious waste and textiles.

Coordinating personnel present in the room are using protective gown over scrub suit and gloves.

Face protection is used: visor/goggles, etc., dependent on the type of infection.

Blood-borne infection: use double gloves and visor/goggles (see chapter "Isolation-Blood-Borne-Pathogens").

Airborne infection: use respirator P3 mask at defined type of infection (see chapter "Isolation Airborne/Droplets".

The door to the room is sign posted.

\section{During Operation}

Few participants: only necessary personnel are present.

The door $(s)$ closed.

Controlled conditions: biological material and used equipment are kept under control.

- Minimal use of suction systems and of other aerosol-forming procedures such as diathermia.

\section{After Surgery}

Anaesthesia is terminated in the operating room.

Transfer of the patient to a clean bed or stretcher in the operating room.

Anaesthetist takes care of the anaesthesia equipment and package of infectious waste, textiles, etc. Bring risk-packed, reusable equipment for cleaning/disinfection. Disinfect trolley/cart and leave it on the operating room during the disinfection time.

Surgical nurse takes care of instruments and equipment and clearing the operating room.

Disinfection of the operating room: surgical nurse informs about the type/extent of disinfection to the cleaner. (See "Disinfection of Rooms and Surfaces".)

Unused equipment is treated as used.

Waste/textiles are transferred to new, clean transport packaging in/at the doorway to the disinfection room or corridor.

Textiles and clothes are taken off. Personnel take off gowns and PPE inside the operating room-at the door. Shoes are left in the room.

The staff participating in the operation change-after shower-to clean scrub suits before new work. 


\subsubsection{Less Infectious Patient: Infectious Surgery Without Spreading to the Surroundings}

Some interventions in infected tissue can be treated as a normal operation if spills/ sprays/dispersion to the environment does not occur, for instance:

- Minor skin infections.

- Local abscesses.

- Acute appendicitis.

- Cholecystitis, etc.

If the degree of infection is uncertain or diffuse, or infection with multiresistant bacteria is suspected, the operation is prepared as described in Sect. 35.10.1. Surgical nurse and the responsible surgeon assess and decide which measures should be implemented before, during and after surgery. In case of doubt, contact the infection control personnel. If full infection control has been performed during the operation and the infected material has been adequately treated, only instruments and equipment used by the operation team should be treated as infected.

\subsubsection{Disinfection of Rooms and Surfaces}

During all surgical interventions, blood splash may be present near the patient. All biological material must be treated as potential infectious. In case of pus infections, special cleaning measures are required. In case of a high risk of spread of infection, a complete disinfection of the room is carried out. In case of minor risk, "spot disinfection" is performed.

\subsubsection{A. General Disinfection, "Pus Wash" or "Infection Wash”}

\section{When To Be Done}

- After surgery in infected tissue where infectious material has contaminated the environment, the situation has been out of control. Floors, walls, fixtures, etc. can be contaminated.

- Contagious disease where the room is considered to be generally contaminated, e.g. MRSA, VRE, other MDROs and tuberculosis.

- In cases where contamination of infected material is massive, the infection is serious and the delimitation is uncertain, general disinfection is carried out.

\section{Line of Action}

1. The person who performs the disinfection procedure:

(a) Single-use gown, waterproof with long sleeves and cuff.

(b) Gloves covering the cuff.

(c) Cap and mask.

(d) Visors/goggles. 
2. Follow the recommendation for clothing as outlined in the hospital's "isolation regimes".

3. In case of massive contamination, most of the soil and biological materials are removed with absorbent material, packaged and treated as hazardous waste. Disinfectants_like chloramine 5\% or PeraSafe_-are applied on contaminated surfaces and equipment with cloth or sponge. Effect time is $60 \mathrm{~min}$ for chloramine and $30 \mathrm{~min}$ for PeraSafe.

4. Equipment used is packaged and treated as infectious. Buckets are emptied and disinfected in the decontaminator. Trolleys, carts and larger equipment are disinfected and left in the operating room.

5. Protective clothing is removed and packaged/treated as infectious.

6. Door(s) are marked with sign and kept closed during disinfection period.

7. After completion of the disinfection period, cleaning is performed. Finish with alcohol wiping of all horizontal surfaces.

\section{Ventilation after Disinfection of Rooms}

1. Calculate approx. $30 \mathrm{~min}$ from the start of cleaning to acceptable ventilation if the department has more than 17 air changes per hour in operating rooms.

2. Calculate at least $1 \mathrm{~h}$ after completed cleaning at conventional ventilation, less than 17 air changes and controlled ventilation.

\section{Gas Disinfection}

Hydrogen peroxide gas disinfection of the room is effective-except for tuberculosis [24-26]. Applied after defined guidelines for rooms, surfaces, ventilated medical devices, ducts/channels and filter. A defined spore test is always needed to check the effect $[24,25]$. For more information, contact infection control personnel.

\subsubsection{B. Spot Disinfection}

Surgical nurse who participated during the procedure assesses the situation together with the surgeon and determines the extent of disinfection. It is only necessary to disinfect the area contaminated by infectious material if the procedure is defined as less infectious; see above.

1. Spill of blood and other organic matter is removed with gloves and absorbent material, packaged and treated as hazardous waste.

2. Suitable disinfectant-chloramine 5\%—is applied on contaminated surfaces and equipment with cloth or sponge.

(a) Effect time-30 min (wiped-off surface).

(b) $-60 \mathrm{~min}$ (dirty surface).

3. PeraSafe can be used instead-effect time $30 \mathrm{~min}$. 


\subsubsection{Disinfection of Equipment and Instruments, Etc.}

\subsubsection{Autoclave}

The inside of the autoclave is cleaned with soap and water one time/week. Follow the guidelines for cleaning, using and checking temperature curves and spore control. For other sterilization methods, follow written procedures.

\subsubsection{Decontaminator}

Flush decontaminator. The machine is designed for liquid waste and washing water with a short flush cleaning/disinfection programme, not suitable for cleaning/disinfecting instruments or highly contaminated equipment.

Instrument washer should not be used to empty liquid materials. The machine has a long programme of cleaning/disinfection of instruments adapted to the department's equipment park with various inserts.

\subsubsection{Control}

Daily: washing machines and flush decontaminators are inspected daily for soaps, chemicals and temperature. Strainers are cleaned and nozzles/washers are checked for cleaning.

Weekly: door gasket is cleaned and silicone treated.

\subsubsection{Soaps and Detergents}

Use only recommended means adapted to current machine. Select the means according to the type of equipment to be cleaned in cooperation with the supplier.

\subsubsection{Thermal Disinfection}

This is used for all equipment where possible. Automated thermal disinfection of equipment is made in decontaminators where the disinfection temperature should always be more than $85^{\circ} \mathrm{C}$ for a specified time.

- Flush decontaminator is $>85^{\circ} \mathrm{C}$ for more than $1 \mathrm{~min}$.

- Washing decontaminator (instrument washer) is $>85^{\circ} \mathrm{C}$.

- >3-5 min when disinfection cycle occurs after the cleaning phase (e.g. KEN machines).

- 10 min when the disinfection cycle occurs during the cleaning phase (e.g. MIELÉ machines).

- Check all machines for the temperature and the purity of washed/disinfected equipment after undergoing thermal disinfection. Particularly enterococci, Clostridium difficile spores, certain other bacteria, norovirus, hepatitis B virus, hepatitis $E$ virus and a number of other viruses are heat resistant and can withstand very high temperatures, especially combined with the rest of organic materials. 


\subsubsection{Chemical Disinfection (See Separate Chapter)}

Agents used for chemical disinfection are approved by the National Medicine Agency and by the hospital's management. A variety of microbes such as gramnegative rods, viruses and fungi may be relatively resistant to chemicals. Therefore, observe working time and concentration of the agent used!

- Chloramine 5\% to surfaces.

- PeraSafe for instruments (and surfaces).

- Aldehyde (glutaraldehyde 2\%) for disinfection of special equipment (optical equipment) that cannot tolerate heat infection and/or is sensitive to other chemical disinfectants. Worked in cabinets with exhaustion and shall not be inhaled!

- Ethanol (alcohol) 70\%: used only for disinfection of clean equipment, clean surfaces, etc.

- Ordinary chemical disinfection has no effect on prions. In case of suspected prion disease such as Creutzfeldt-Jakob's disease, contact the hospital hygiene personnel. See chapter "Technical Disinfection and Prions".

Follow the recommendation on the container's label regarding the durability, range, effect, working time, etc. All containers with disinfectant must be covered with a tight lid and placed with restricted admission.

\subsubsection{Pretreatment of Used Equipment Before the Chemical Disinfection}

- Biological material should not dry on the instruments.

- Wear gloves, waterproof gown and hood/surgical mask/glasses/visor. Do not mess or spray!

- Carefully remove visible contaminants with absorbent material.

- Composite equipment, instruments and objects are maximally dismantled before putting into the disinfectant.

- All surfaces must be below the liquid level. Any cavity may be filled with disinfectant. Follow the recommended effect time, and cover with lid.

- Clean and rinse with water to get rid of all disinfectants, and dry prior to storage, if desirable, or prepare for sterilization.

- Check if the disinfectant should be changed between processes-follow routines.

- Work is performed under exhaust and with a good ventilation.

- Hand washing after work with chemicals and after the use of gloves.

\subsubsection{Preoperative Routines}

(See also chapter on "Prevention of Postoperative Wound Infections".) 


\subsubsection{The Patient}

Shower or body wash-including the hair-should be performed the day before and on the day of surgery. It should be done at least $2 \mathrm{~h}$ before the operation, to decrease the release of skin cells and bacteria from the body. Before ultraclean surgery (orthopaedics/heart/vessel), it is recommended to use chlorhexidine soap (for instance, Hibiscrub). Check if the navel and nails are thoroughly cleaned. Nail polish should be removed from the fingers and toes. The hair should be clean and washed with chlorhexidine shampoo. The patient should have a good oral hygiene. Jewellery, watch, makeup and face cream should be removed.

Clean linens and clean bed for transport to the surgery department, including emergency, if possible. Patients with open, infected wounds or other infection should have a new, clean bed the day of surgery. The contaminated bed will be left on the patient room and treated as infected with disinfection. New beds and linens to all after surgery!

For hair removal, if needed, use the electric/battery clippers or depilatory cream. Shaving increases the risk of wound infections. Avoid removing the hair if unnecessary. Clean and disinfect the clipper after use. Disposable heads of the clipper are used, with new blade for each patient.

\subsubsection{Surgical Team}

Surgical hand disinfection: see separate chapter for "Surgical Hand Disinfection" $[27,28]$.

\section{Sterile Dressing (Gown and Gloves)}

- Gowns are dressed just inside the door of the operating room. Avoid close unsterile contact with others.

- Preferably use double gloves during operations that may lead to perforation and during surgery on patients with blood-borne infections (hepatitis, HIV, etc.).

- The package with sterile gown, gloves and wipes is opened by others immediately before dressing to avoid contamination.

- The gown is folded inside out; lift the upper part.

- Keep the hands up; slip into the sleeves to the wrists of the gown.

- The assistant helps pull in place sleeves, from behind, and closes posteriorly. Do not make the outside of the gown unsterile.

- Take on gloves when the hands are still covered by the sleeve (closed method).

- Gown front and gloves must not be made non-sterile.

- Take the right glove with the right hand (right-handed) so that the glove's fingertips are facing the shoulder.

- Turn the glove around and on the hand.

- Take the left glove with the right hand, and pull it around and on the left hand.

- NB! Assisted dressing of gloves is the safest and prevents contamination $[29,30]$. 


\section{Change of Sterile Gown and Gloves Peroperatively}

Coordinating surgical nurse in collaboration with sterile dressed executive surgical nurse-away from the area of operation:

- Drag the cuff of the sterile gown over the gloved hand.

- Remove the gown and gloves.

- Alcohol disinfection of the hands.

- New sterile gown and gloves, as above.

\section{Opening of Sterile Packages and Drapes Equipment}

Sterile executive surgical nurse should ensure that instruments and equipment are sterile and in proper condition and that the use and composition of the equipment are known for the surgical team. The laying of sterile instruments should take place without the other activity in the operating room. This is to reduce burden of dust and microbes on instruments. Afterwards cover sterile.

- No sterile packages are opened before the sterile executive surgical nurse is ready.

- The sterility of opened equipment is continuously monitored and covered until use.

- All implants are sterile covered after unwrapping. Implants should not be touched unnecessarily with sterile gloves because of undesirable coatings and risk of debris from small punctures in the gloves. Instead use, for instance, suitable sterile tweezers/forceps.

\subsubsection{Disinfection of Surgical Fields: Field Washing}

The size of the surgical area to be disinfected is decided by the surgeon. By insufficient disinfected area, the surgeon may come outside the area and make the operation unsterile. All disinfection should be dried on the skin (for effect), before the sterile covering. If the cover is wet by disinfectants, it may easily loose during operation and make the area non-sterile.

\section{Sterile Cleaning Kit with Sterile Forceps and Sponges/Swabs}

Containers with disinfectants should be used for only one operation and discarded afterwards!

Methodology for preoperative disinfection, time use, the number of applications of disinfectant, etc. may vary from 1-2 $\mathrm{min}$ to $5-10 \mathrm{~min}$ and is poorly documented; see background information. However, follow the local guidelines until others are decided!

- Intact skin: Chlorhexidine alcohol $5 \mathrm{mg} / \mathrm{ml}$-Single use (disposable).

- Wound or mucosa: Chlorhexidine $0.5 \mathrm{mg} / \mathrm{ml}$ in aqueous solution or chlorhexidine $1.0 \mathrm{mg} / \mathrm{ml}$ in aqueous solution.

- Ears: Chlorhexidine is ototoxic!. 
Two methods-A and B-are described; the author recommends Method B (see below).

1. General:

- Disinfect the outer frame, at least $10 \mathrm{~cm}$ outside the sterile area.

- Disinfect the surgical area thoroughly with plenty of disinfectant, but not so much that the patient lies on wet bedding.

- Start in the middle and disinfect outwards.

\section{Method A: Two Times Disinfection-Washing Process, a Total of 2 min, and Additionally Drying}

- Duration of disinfection process: at least $1 \mathrm{~min}$.

- Reapplication starting in the middle.

- Finish with the outer frame. Avoid contamination from the non-disinfected skin.

- Duration of cleaning process: at least $1 \mathrm{~min}$. Do not contaminate when sterile covering.

- Allow the area to dry before sterile covering.

\section{Method B: Five Times Disinfection-Washing Process, a Total of $5 \mathrm{~min}$, and Additionally Drying}

- Disinfect the surgical field thoroughly with plenty of disinfectant, a total of at least five times.

- Make first a border around the area of operation.

- Field disinfected should be at least $10 \mathrm{~cm}$ larger than the sterile cover area.

- Field within the framework is disinfected.

- Start in the middle and disinfect outwards.

- Let the disinfectant work for at least 1 min each time.

- New application always starts in central operation field. Do not wash out as far as the last time (contamination from non-disinfected skin).

- Let it act at least $1 \mathrm{~min}$ in the end until the skin is dry.

- When sterile covering, the skin should be dry.

- When disinfecting areas of the abdomen, the umbilicus should be disinfected first with Q-tips before the frame of the field is created and the rest of the field is disinfected.

- Contaminated zones like fistulas and stomas are disinfected first before the rest of the field is disinfected as usual. Fistulas, stomas, etc. are disinfected using tupfers and corn tongs (forceps), and chlorhexidine $0.5 \mathrm{mg} / \mathrm{ml}$ in water solution before the rest of the surgical area is disinfected with chlorhexidine alcohol $5 \mathrm{mg} / \mathrm{ml}$.

2. Regular square disinfection:

- Abdomen and minor surgery: tupfer/forceps.

- Large fields, orthopaedics and heart/thorax: swabs/gloves. 
3. Disinfection of extremities:

- Disinfect from the highest point and down.

- The outer edges are finally disinfected.

4. Disinfection of the perineum area.

- Compress/forceps.

- Disinfect first the genitalia and outwards to the outer frame. Disinfect the anal region finally.

- Chlorhexidine $0.5 \mathrm{mg} / \mathrm{ml}$ in aqueous solution.

5. Fields with contaminated areas (anus, infected wounds).

- Disinfect the area from the clean to the most contaminated area.

\subsubsection{Sluice Functions}

The patient is coming in clean linens and clean bed to bed sluice.

Staff are entering through the dressing room after retrieving "green cloths" on the textile room. Hand hygiene after changing clothes, before leaving the dressing room and before entering the surgical department. The same way out when leaving the operation department. Scrub suits should be used only in the operation department. After urgent care or other activities outside the green zone, the way back is via the sluice with the change of scrub suit. This applies to all traffic to and from the department.

Equipment and instruments $\mathrm{mm}$. that is to be brought out of the operation department must be clean inside and outside. If disinfecting the inner parts is inapplicable, the equipment should be specifically labelled, and the receiver should be noted of the condition.

Equipment that is brought into the department must be clean inside and outside. It is also desirable that the particle quantity that follows the equipment is minimized. Reusable equipment that cannot be disinfected in an appropriate manner should not be taken into the department.

Equipment must not be brought to the surgical department for disinfection/sterilization. This should be done elsewhere.

\subsubsection{Surgery on Cases with Drug-Resistant Mycobacterium tuberculosis [89-91]}

(See also chapter "Strict Isolation".)

\subsubsection{Mycobacterium tuberculosis}

- Survival for 1 year if not exposed to sunlight or UVC [91].

- Low infection dose; one bacterium may infect.

- Chloramine 5\%, PeraSafe and glutaraldehyde may kill the bacteria. Alcohol and Virkon (Kalium persulphate 50\%, sulphaminic acid 5\%) have no sure effect. There is no any known effect of gas disinfection [1, 26, 91, 92]. 
- Respirators-P3 mask (without valve)—provide respiratory protection if used properly.

- Patient with infectious tuberculosis is isolated as contact and airborne infection.

- During surgery, opening into foci with tubercle bacteria may result in contaminated air and environment in the room.

\subsubsection{Pretreatment of Patient}

- Apply Hibiscrub body disinfection in the evening and the morning before the operation.

- The patient is transported in clean clothes and in clean bed directly to the operating room. Disinfect the wheels of the bed before the transport starts.

- The patient uses a respiratory protection during transit, possibly surgical face mask.

- The bed is treated as "strict isolation", is covered with plastic and is returned to the isolation unit for disinfection (see chapter "Strict Isolation").

\subsubsection{Time of Planned Operation/Functional Conditions}

- Operations should take place at the end of the day.

- Minimal activity takes place in other operating rooms.

- Do not use LAF rooms-TBC particles may penetrate LAF ceiling.

- Preferably use a defined theatre with negative pressure-for surgery on infections.

- Regular operating room without negative pressure: switch off the ventilation for the operating room separately during surgery and $2 \mathrm{~h}$ after completion of disinfection, and close and cover all ventilators.

- The ventilation system should be test-run beforehand.

\subsubsection{Ventilation-The Establishment of Mobile Negative Pressure}

- Aggregates creating a negative pressure $(-15 \mathrm{~Pa})$ in the operating room may be installed. The exhaust air is disinfected/hepafiltered through a unit before sending it outside directly through channels in the wall or in the window (not in ventilation ducts). Air from all air-cooled equipment is also connected to the exhaust duct (unit). Hepafilters are put on air intake devices in the operating room to stop contamination of the inner parts of technical equipment.

- After use, disinfect all the equipment outside with chloramine 5\% in $1 \mathrm{~h}$ or PeraSafe at the same time. The entire aggregate unit and other devices are then packaged in for further disinfection, if possible. Check if internal parts of the equipment can withstand immersion in PeraSafe or glutaraldehyde-see chapter "Disinfection".

\subsubsection{Preparation-Normal Operating Room Without Negative Pressure}

- Remove excess inventory, and put plastic over the wall's solid materials in the operating room that are difficult to treat with chloramine 5\%, and do the same for the hand hygiene room, induction room and disinfection room. 
- Tape over all through-put closet. These should beforehand be emptied.

- Tape over the exhaust ducts and supply air ducts.

- Check the temperature of decontaminators and washing machines beforehand.

- Obtain necessary packaging for infectious waste and used equipment.

- Arrange for special transport of infectious waste for combustion.

- Drapes with instrument table must be completed and covered before the patient arrives. Make sure that all equipment necessary for the operation are in the room.

- For anaesthesia machines and equipment, use disposable equipment on a separate board.

- Signs of doors should be in strict isolation.

- Only necessary personnel should be present; use the intercom-preferably not the phone.

- Personnel who participate should be healthy (normal immune status), not pregnant and tuberculin positive.

\subsubsection{Clothing and PPE-For All Present}

- Gown with long arms and cuff_-disposable surgical gowns.

- Operation cap covers the hair and ears.

- Hood covering the head and neck.

- Gloves (double for the operating and anaesthesia team).

- P3 mask-respirator (without valve).

- Room-bound shoes.

- Surgical and anaesthesia team uses in addition visors/goggles.

Close the doors-not permitted entrance during surgery.

If the doors must be opened, open it carefully due to the circulation of air and negative pressure.

\subsubsection{Peroperatively}

- Hepafilter on the ventilator opening sucks air from the room to cool the machine.

- Avoid diathermy and suction that cause splashes and aerosols.

- Work slowly and safely, using good time.

- The coordinating nurse is repacking the used equipment in infection bags/boxes as it is finished.

- External personnel on the disinfection room are using the same PPE and attire as internal coordinating surgical nurse and receive packaged equipment, infectious waste, etc. from the operating room for further treatment.

\subsubsection{Postoperatively (Personnel-Equipment-Waste)}

- Personnel who are leaving the room are moving to the door of the hand disinfection room and there take carefully off gloves, gown and finally mask and shoes, disinfecting the hands between each procedure. See strict isolation on how to do doffing. 
- Disposable equipment is put in the infection sack and shoes in a separate sack for decontamination. Infection bags are placed in the operating room. Smaller sacks can easily be packed in infection containers.

- Wash the hands thoroughly in hand disinfection room, and then go directly to a predesignated shower, and change into new clothes (all items).

- Reusable equipment is placed in the metal boxes, disinfected externally with $70 \%$ alcohol before handover to the person on the disinfection room compartment. Put the whole box and equipment in the washer/decontaminator.

- Personnel in the disinfection room receives all infectious waste that is double packed in the doorway to the disinfection room.

- The outer packaging is disinfected with alcohol at the door to the corridor-from the disinfection room. It should be perfectly clean on the outside when the infectious waste is placed in a clean container (yellow box or bag) and brought to the transport unit.

- The transporter should be informed and is wearing gloves, ordinary surgical masks and gown (regular wash after use) during transport to the collection point.

- Infectious waste is transported immediately for direct combustion.

\subsubsection{Samples for Culture-Pathology}

- Samples for laboratory examination are double packaged as described above and brought personally to the laboratory. NB! Prior arrangement and information with the laboratory. Microbiological examination is very important for further antituberculous treatment.

\subsubsection{The Patient}

- Awake from narcosis in the operating room.

- Transfer to new, clean bed, and wheels are disinfected in the intduction room before the patient is transported out.

- Transport for airborne isolation with negative air pressure. Anaesthesia personnel must follow, if needed.

- If the patient cannot breathe by himself, use handbag during transport.

- If the patient is on respirator, use a type that is easily disinfected afterwards.

- Anaesthesia/intensive personnel should—along with the rest of the team-take responsibility for the patient if ventilator treatment is necessary.

\subsubsection{Disinfection of Rooms and Surfaces}

- Disinfection of rooms and surfaces should be done with PPE in all rooms where the patient, equipment and personnel have been: operating rooms and corresponding rooms (hand disinfection room, induction room and disinfection room). See chapter "Strict isolation".

- Chloramine 5\% is used on all surfaces, including walls, ceilings, through-put cupboards and closets/drawers. 
- Staff are using PPE as described above, end with a shower and change into clean clothes.

- See chapter "Disinfection".

\subsubsection{Tuberculin Test}

All persons who attend per-postoperatively check tuberculin test in advance, if possible.

\section{If Personnel Are Infected What Happens}

1. If the above guidelines are followed, nobody should be infected with TB.

2. If it still should happen, about $10 \%$ of those infected can be sick.

3. If symptoms occur, early treatment is associated with a good prognosis.

4. If one gets sick/infected, it will be defined as an accident at work and treated as an occupational injury.

5. Accidents at work (not able to work) may lead (in Norway) to full salary for 2 years + a sum of compensation from insurance pools or other local solutionscheck this.

\subsection{Background Information}

Infection control routines in the operation department are based on many single factors from experience, documentation and expert panels for more than a hundred years [1-13]. Procedures may be evidence-based, or not. Unfortunately, too many procedures may still lack evidence. Some factors, like hand disinfection versus no disinfection and surgical site disinfection versus no disinfection, may probably never be investigated because of ethical problems. Consequently, consensus and guidance are used to a great extent.

Surgery opens into sterile tissues for hours, during massive tissue damage by knife, diathermy, clogging of vessels, pressure against and drying of tissues, decreased blood supply, impaired phagocytosis and reduced local infection defence. Microbes deposited in devitalized tissues may find a good basis for growth and proliferation.

\subsubsection{Clean Operating Environment}

Already in the 1880 s, a clean operating environment was important. Rubber surgical gloves came about in 1910, antibiotics were used from the 1940s and later on came diverse improvements on cleanliness and infection prevention in connection to operational activities [31]. Lister disinfected everything around him and moved operating rooms as far as possible away from other activities but operated in 
private clothes. From 1930 on, clean air in the operating room was appropriate but quite necessary for prosthesis and transplant surgery from the 1960s $[1-5,12,13$, $18,19]$.

Still are, up to $70 \%$ of surgical sites contaminated during surgery with microbes from adjacent skin areas, the air around the operation area and of the operational staff, or instruments that have been exposed and moved with particles and microbes toward the operation area.

A clean operating environment is dependent on clean air, clean room, clean equipment, clean patient and clean personnel. The bacterial number quickly reaches 300-600 colony-forming units (CFU) per cubic metre $\left(\mathrm{m}^{3}\right)$ of air, mostly freed from the skin, clothing, hair and upper respiratory tract from those present. In each CFU, several bacteria can be present simultaneously; thus, the real number is higher.

In a good operating theatre, the CFU value must be down to less than 100/ $\mathrm{m}^{3}$ of air and in ultraclean rooms less than $10 / \mathrm{m}^{3}$ air. To accomplish this, personnel are dressed in clean scrub suits with cap and surgical mask, and the surgical team also uses sterile surgical gowns. In addition clean filtered air at a positive pressure is ventilating the operating room with $17-25$ air changes per hour $[22,23]$.

\subsubsection{Identification of High-Risk Patients}

Surgical site infections (SSIs) were studied among 58,500 patients operated in the 1970s in the United States (SENIC study) [5]. More than 90\% of high-risk patients could be readily identified in advance by four factors: abdominal operation, operating time more than $2 \mathrm{~h}$, contaminated or highly contaminated surgical wounds and patients with three or more diagnoses [5]. By giving each of these factors weight one (1) and counted together, the infection rate with 0 point was low $(<1 \%)$, with 1 point medium (3-4\%), 2 points high (10.8\%), 3 points even higher (18-20\%) and 4 points highest (28-30\%). A study of 59,400 operated patients (1975-1976) showed almost identical findings [5]. Later on more sophisticated methods were developed.

\subsubsection{Sterile Gloves: Surgical Gloves}

Surgical gloves must be strong and soft and have few holes. CDC estimates that from 1000 to 10,000 bacteria pass small punctations in surgical gloves, which are reduced to about 100 by good hand disinfection [28]. The occurrence of SSI after using sterile versus non-sterile gloves is never explored, nor effects of double gloves are well documented [32]. Double gloves reduce the perforation of the inner glove, and the use of indicator systems means that most holes are discovered during surgery [32]. 
Cruse and Foord found that if gloves were punctated, the proportion of SSI was $5.7 \%$ versus $1.7 \%$ without punctation [2]. Perforation is greatest during complicated operations: for orthopaedic team about $40 \%$ and for soft tissue surgery $16 \%$ [33]. By hip operations, it is proven 1-2 perforations in $25 \%$ of operations, $8 \%$ with perforated both gloves, and this was detected during the operation only in a small proportion of the teams [34-37]. Most perforations are detected on the left index finger or thumb [34].

A study from Molde, Norway, proved a hole in one of the three gloves, which led to the use of double gloves during all operations [36]. In the Department of Neurosurgery, Oslo University Hospital, about 1000 gloves were examined after craniotomy [35]. There were holes in $16.5 \%$ of the outer glove, and in two of the three cases, this was not discovered during surgery. The surgeons had most holes $(22 \%)$, mostly on the non-dominant hand. The use of indicator gloves gave a protection of approximately $99 \%$ [35].

Gloves become easily contaminated during the operation. After disinfection and sterile covering of the operation area, bacteria were found on 5/42 surgical gloves and before prosthesis insertion on 10/42 gloves [38]. Nineteen species of bacteria were detected, of which 16 different coagulase-negative staphylococci and 1 each of Micrococcus, Enterococcus and Bacillus sp. [38].

In one study, $6 \%$ of the surgical team had bacteria on fingertips immediately after surgical handwash and sterile gloving, and at the end of the operation, $6.6 \%$ of the gloved fingertips and $51 \%$ of fingertips without gloves were contaminated with bacteria [27]. In all, $96.6 \%$ of surgeons had sterile glove fingertips at the end of the operation [27]. S. aureus and 17 different gram-negative bacteria among common skin bacteria were detected, mostly before (after surgical hand disinfection) but also after the end of operation [27]. Gloves are replaced when possibly contaminated and always before moving from a contaminated to a more clean area.

Technique of sterile dressing of surgical gloves is discussed [29, 30]. It is easy to contaminate the sterile gown when dressing sterile gloves. Both open and closed technique may lead to $100 \%$ contamination rate, concentrated around the forearm and wrist [29]. This may be avoided by using assisted dressing by a sterile dressed surgical nurse [29]. Reversion of the glove cuff may happen relatively often during surgery [30]. The reversed part may be contaminated with the operator's hand flora. The assisted and closed technique will also reduce this problem [30].

\subsubsection{Dressing of Surgical Teams}

Dressing retains loose skin particles, the hair and bacteria in place in the surgical team while protecting against organic matter from the patient. Bacterial amount in the operation theatre comes mostly from the surgical team and from the environment. Each person is releasing millions of tiny skin particles every day and even 
more during physical activity and sweating [39, 40]. About $10 \%$ of particles are carrying bacteria. Large amounts of bacteria in the facial-head-ear-neck area of the surgical team may be transferred to the surgical wound if special air currents and covering are not taken into account $[39,41]$.

Tight clothing is required [42-51]. Cotton clothing is comfortable but allows loose skin particles, $2.5-20 \mu \mathrm{m}$, go through the $80 \mu \mathrm{m}$-sized pores of the fabric, and movement increases the liberation of skin particles. Dense, particle-reducing textiles reduce the amount of bacteria and particles in the air and thus the deposition on surfaces, instruments and equipment [22, 23, 43, 44].

Proper attire in LAF rooms is important [18, 45, 46]. Microbes and skin particles are released from the eyebrows, forehead and ears, often in larger quantities from the ears than from the forehead and eyebrows [41]. Therefore, it is recommended to use exhaust helmet or good covering, especially of the ears and hair [41].

The surgical gown should be big enough and comfortable on, tight around the neck and cover well also the back. The arms with cuffs should not be too short, which may lead to excessive contamination. Some are using a seal around the wrist [52].

Packages with sterile surgical gowns and gloves are opened just before dressing since studies show that more than two out of three open sets quickly become contaminated with bacteria [53]. Bacteria survive long in textiles and constitute a source of infection [54].

\subsubsection{Hood-Operation Cap}

Hood or cap should cover the hair and ears and sit tightly on. Without a cap, the amount of bacteria in the air increases 3-5 times and sedimentation in the surgical wound ca. 60 times [18, 45, 46, 49].

Fake operations have demonstrated that in vertical ultraclean air, the CFU in the operation area increases more than 22 times in the absence of operation cap and surgical mask [46]. Using a cap without a surgical mask, the increase is up to 15 times, and using the surgical mask, without cap, more than 4 times, and by using cotton gown, the CFU in the surgical wound increases more than 6 times [46].

\subsubsection{Shoes}

In orthopaedic surgery, there is a large blood contamination of the personnel's shoes $[55,56]$. Therefore, use washable shoes, with shoe washers and drying programmes to reduce transmission of infection-especially blood-borne infections-but also to prevent SSIs [56]. 


\subsubsection{Surgical Mask (SM)}

Cochrane studies show insufficient documentation for the efficacy of surgical face masks with regard to SSI [57]. Labelled albumin studies show continuous deposition of particles from the face and ears to the surgical wound and that this "flow under" the surgical mask if it is not sealed in the bottom [58]. Few bacteria are released to the air by quiet breathing through the nose but are increasing rapidly by whispering or speech [58]. In all, 24 people spoke against a blood agar plate $30 \mathrm{~cm}$ from the mouth-with and without SM. Without a surgical mask, there was a spread of bacteria, while the use of mask stopped the spreading [59].

Surgical mask prevents transmission of bacteria and droplets/saliva from the upper airway. In all, ten men with beards, ten without beards and ten women were examined [60]. They were talking towards agar plates $15 \mathrm{~cm}$ below the lips. By much movement of the mask ("wiggling") came the most bacteria from men with beards and women, but not from men without beards. When the mask was set fastnot wiggling - significantly more bacteria were released to the air from bearded men than from newly shaved men and from women. The conclusion was to avoid loose unstable masks and to remove the beard [60].

Blood and tissue contamination. The use of surgical mask and eye protection (visor/goggles) reduces blood contamination of the eye mucous membrane and upper respiratory tract. Blood-borne viruses may penetrate the conjunctiva [61].

- In a study of vascular surgery, the visor and face masks were blood contaminated on the main surgeon in 51\% and 32\% of the operations, respectively; on surgeon 2, 36\% and 42\%; on assistant, $36 \%$ and $12 \%$; and on surgical nurse, $10 \%$ and $4 \%$, respectively [62]. Prolonged operation time increased blood contamination [62].

- Angio-procedures resulted in blood spill and splash in 23 of 100 procedures; eye protection and face masks were recommended [63].

- By vaginal and caesarean delivery, face visors were blood contaminated in, respectively, 32\% and 50\% of the cases [64]. At vaginal births, the contamination was undetected by half of the personnel and by caesarean undetected by $90 \%$ [64].

- Endo et al. [65] examined 600 surgical face masks with visors or face shield and found that $66 \%$ were blood contaminated: at eye level $37 \%$, in eyebrow elevation $38 \%$ and face masks $60 \%$. Surgeon 1 had contaminated masks with visors in $84 \%$ of cases, the surgeon $269 \%$ and surgical nurse $46 \%$ [65]. The greatest contamination occurred during vascular surgery (75\%), neurosurgery (70\%), gastrointestinal surgery (60\%) and orthopaedic surgery (60\%) [65].

Splash of blood is most often invisible. Blood contamination on the visor is in most cases less than 0.6 millimetres in diameter [66]. Most blood contaminations 
are smaller than $1 \mathrm{~mm}$. Most of the blood contamination during surgery is invisible, and staff must protect themselves against this [66, 67].

Despite different attitudes to the use of surgical face mask, there is little doubt that the mask and visor protect against blood/tissue transmission from the patient during surgery. If the staff is talking, coughs or sneezes, the surgical mask may protect against those secretions from the upper respiratory tract or otherwise may spread far away, also to the wound [58-62, 68].

\subsubsection{Sweating: A Challenge}

Many are sweating from the forehead. Sweat samples taken from 42 people during orthopaedic surgery showed that $42 \%$ were positive for microbes, mostly coagulase-negative staphylococci, Klebsiella sp. in one sample and MRSA in another [69].

\subsubsection{Surgical Site Skin Disinfection}

Cochrane studies cannot conclude regarding disinfection of the surgical field [70]. Out of ethical reasons, evidence studies are lacking, with respect to disinfection versus non-disinfection. It is believed that disinfection of the operation area reduces SSIs [70-72]. The methodology for the application, "scrub" or "painting," of disinfectant is not well described [7, 8, 70-72]. Single studies vary in scrub and paint, and the time of the disinfection process varies from 1 to 5-10 $\mathrm{min}$ [72]. Chlorhexidine alcohol has a good long-term effect [70-72].

Recolonization of the disinfected skin area occurs soon afterwards [73]. Bacteria from the patient's skin, relatively far away from the operation area, migrated into the area in 40 of 40 studies during orthopaedic surgery, despite good barriers around the wound. Bacteria can also come to the wound hematogenously or lymphogenously.

Adhesive coatings for protection of the surgical field; Cochrane and other studies find no good evidence — at all, and it may even increase the infection rate $[74,75]$. Plastic wound retractors can possibly reduce the effect of bacteria in gastrointestinal surgery [76].

\subsubsection{Technique}

Technical expertise, well-functioning operational team and excellent checklists are essential for a successful operation and reduction of SSIs [12].

Stick injuries happen frequently - up to one in five operations. The use of double gloves protects. The glove may work like a pacifier by dragging off most of the 
blood and tissues. A glove may reduce blood volume transferred with 52\%. Gloves protect also the patient's tissue from the surgeon's skin flora and blood. Stick injuries are underreported.

- In England, 42 surgeons had 840 needlestick injuries during 2 years, hence 126 with bleeding [77]. Only one of four surgeons used double gloves, and when blood-borne viruses are known, only 50\% used double gloves. Senior surgeons had more stick injuries and reported less frequently than junior surgeons [77].

- In Scotland, $1.4 \%$ of operating surgeons were infected with hepatitis $\mathrm{C}$ in 1999.

- Magnetic flat instrument deposition reduces puncture injuries by delivery of instruments [78].

- All types of blood contamination agents can be transmitted by needlestick injury-both ways. By aerosol, blood-borne viruses can be transferred through the conjunctiva [61].

- The use of bipolar diathermy increases air contamination of blood and tissue more than monopolar diathermy [61].

- Dentist, surgery and autopsy rooms have been examined for blood aerosols [79]. The rooms are all the same with regard to air samples; $38.6 \%$ were positive for blood, i.e. a mean of $0.10 \mu \mathrm{g}$ of $\mathrm{Hb}_{\text {per }} \mathrm{m}^{3}$ of air [79]. There are many samples of blood-borne infections among the operating team during surgery [80].

- Diathermy needles can be highly contaminated with protein that should be removed between operations [81].

\subsubsection{Storage in the Operating Room}

Storage in operating rooms should not be established because of bioburden. Sutures are particularly susceptible to colonization with slowly growing Mycobacteria, coagulase-negative staphylococci and other robust microbes [82].

\subsubsection{2 "Risk Personnel"}

May be personnel with skin infections, infections or carrier state of group A streptococci, MRSA, ESBL and other MDROs, nasal carrier of $S$ aureus, beard, unlimited activity and access, untrained personnel, and personnel that are not following personal hygiene, hand hygiene, glove and mask rules, dressing routines, behaviour in sterile areas, etc. These are known situations where personnel may pose a risk for the patient and for other staff. 


\subsubsection{Other Risk Factors}

These are poorly organized department, inadequate management, insufficient space, lack of storage conditions, ventilation and pressure conditions that are not balanced, building activities, poor cleaning between operations, missing filter for intake air, open through-put cabinets that brings contaminated corridor air in, operating and preparing the next patient in the same room at the same time and other "shortcuts", etc. [12, 83-85]. There may also be challenges associated with loaner instrumentation [86].

\subsubsection{Postoperative Phase}

Postoperative and intensive departments are challenges for recent surgery patients since bacterial load combined with high antibiotic consumption and often dormitory organization leads to a relatively high burden of infection $[12,87,88]$.

An outbreak of 39 infections (17.5\%) among 223 heart surgery patients in North Carolina, USA, was tracked to the cardiovascular intensive care unit where the infection appeared 1-6 days after surgery [87]. Pathogenic bacteria were found in and around a heavily polluted sink, on the hands of staff after handwashing, on contaminated "clean hands" and in the air near the sink. The sink was closely located to the patient beds where the air around the nearest bed had the same microbes as in the air around running water in the sink (aerosols). After actions, including closing off the sink, the infection rate was reduced to 5.6\% [87]. Singlebed rooms in ICUs may reduce the number of infections, and length of stay becomes shorter [89].

\subsubsection{The Ageing Wave: Prognoses}

In the United States, it was calculated that during the period 2000-2020, there would be a $56 \%$ increase of infection in elderly over 65 years and cardiovascular and orthopaedic surgery would increase by, respectively, $42 \%$ and $28 \%$. If infections with $S$. aureus, MRSA and other MDROs are increasing as is the fact today, the problems around SSIs may become much greater and more serious than for a few years ago. Therefore, a restrictive infection control combined with a restrictive antibiotic policy is very important preventive means to reduce SSIs in the future surgery.

\subsubsection{Operation of a Patient with Multidrug-Resistant Tuberculosis}

For example, patient is not well treated for Mycobacterium tuberculosis of the lungs [90-93]. The bacteria developed resistance to most drugs, first- and second-hand 
choices, and caverns in the right lung occurred, while the left lung capacity was in order. The patient was prescribed new drugs (linezolid, augmentin, etc.). The bacterium was sensitive to these medications, but it was only a question of time before the development of resistance.

\subsubsection{Advantages of Surgery for Lung Cavern and Multidrug- Resistant M. tuberculosis}

- If caverns are not removed, resistance to new drugs may probably quickly develop due to poor penetration into cavern tissue and low concentration of the agent.

- Experiences from the United States show that if surgery is chosen, there must be effective drugs given in 24 months postoperatively. If there are no effective drugs (the bacterium is totally resistant), surgery will not provide any benefit for the patient. No treatment (resistance to all) will lead to a poor prognosis [90-93].

- The patient can be cured for multidrug-resistant pulmonary tuberculosis if surgery is done, combined with effective, intensive medication.

- If the effect of the treatment is curative, a severe, drug-resistant infection source is removed from the society.

\subsubsection{Risks Associated with Surgical Treatment of Multiresistant, Pulmonary Tuberculosis}

- Further development of tuberculosis in the rest of the lung tissue.

- Too small residual lung function-the patient does not come off the respirator.

- Fistula formation with pus secretion to the respiratory tract or externally.

- If there is no effect of the surgical and medical treatment, this would be a greater problem for the patient and for the environment than earlier (ventilator, fistula with pus, etc. and strict isolation until death).

(The patient was operated two times and the right lung was removed. He survived and was cured.)

See also chapters on "Prevention of SSIs, Strict Isolation, Tuberculosis".

\section{References}

1. Charnley J. Postoperative infection after total hip replacement with special reference to air contamination in the operating room. Clin Orthop. 1972;87:167-87.

2. Cruse PIJ, Foord R. The epidemiology of wound infections. A 10-year prospective study of 69,939 wounds. Surg Clin North Am. 1980;60:27-40.

3. Lidwell OM, Lowbury EJL, Whyte W, Blowers R, Stanley SJ, Lowe D. Airborne contamination of wounds in joint replacement operations: the relationship to sepsis rates. J Hosp Infect. 1983;4:111-31.

4. Lidwell OM, Lowbury EJL, Whyte W, Blowers R, Stanley SJ, Lowe D. Infection and sepsis after operations for total hip or knee-joint replacement: influence of ultra clean air, prophylactic antibiotics and other factors. J Hyg (Lond). 1984;93:505-29. 
5. Haley RW, Culver DH, Morgan WM, White JW, Emori TG, Hooton TM. Identifying patients at high risk of surgical wound infection. Am J Epidemiol. 1985;121:206-15.

6. Andersen BM. Surgical department. In: Handbook of hygiene and infection control. Oslo: Ullevål Hospital; 1996. p. 211-36.

7. Mangram AJ, Horan TC, Pearson ML, Silver LC, Jarvis WR. Guideline for prevention of surgical site infection, 1999. Hospital Infection Control Practices Advisory Committee. Infect Control Hosp Epidemiol. 1999;20:250-78.

8. Nichols RL. Preventing surgical site infections: a surgeon's perspective. Emerg Infect Dis. $2001 ; 7: 220-4$.

9. Ventilation of operating theaters. Center for Health Technology Assessment, SINTEF UNIMED, Oslo. 2001.

10. Fletcher N, Sofianos DM, Berkes MB, Obremsky WT. Prevention of perioperative infection. J Bone Joint Surg. 2007;89:1605-18.

11. Øgrey T, Kristoffersen K, Hochlin K, Andersen BM, Tollefsen T. Operation department. In: Handbook of hygiene and infection control. Oslo: Ullevål University Hospital; 2008. p. $524-45$.

12. Greene LR, Mills R, Moss R, Sposato K, Vignari M. Guide to the elimination of orthopedic surgical site infections. APIC. 2010:1-79.

13. Tsai DM, Caterson EJ. Current preventive measures of health-care-associated surgical site infections: a review. Patient Saf Surg. 2014;8:42.

14. Treakle AM, Thom KA, Furono JP, Strauss SM, Harris AD, Perencevich EN. Bacterial contamination of healthcare workers' white coats. Am J Infect Control. 2009;37:101-5.

15. Sultan MJ, Alm A, Hindmarsh A, Greatorex RA. Security swipe cards and scanners are a potential reservoir for hospital-acquired infection. Ann R Coll Surg Engl. 2009;91:155-8.

16. Kolmos HJ, Svendsen RN, Nielsen SV. The surgical team as a source of postoperative wound infection caused by Streptococcus pyogenes. J Hosp Infect. 1997;35:207-14.

17. Talbot TR, May AK, Obremsky WT, Wright PW, Daniels TL. Intraoperative patient-to-healthcare-worker transmission of invasive group A streptococcal infection. Infect Control Hosp Epidemiol. 2011;32:924-6.

18. Friberg B, Friberg S, Östensson R, Burman LG. Surgical area contamination - comparable bacterial counts using disposable head and mask and helmet aspirator system, but dramatic increase upon omission of head-gear: an experimental study in horizontal laminar air flow. J Hosp Infect. 2001;47:110-5.

19. Hambraeus A, Bengtsson S, Laurell G. Bacterial contamination in a modern operating suite. 3. Importance of floor contamination as a source of airborne bacteria. J Hyg (Lond). 1978;80:169-74.

20. Norwegian Board of Health. Guidelines for microbial control of air in the room where it is performed surgery and major invasive procedures (operating room). Circular IK-2/97.

21. Norwegian Board of Health. Standards of hygiene and air quality by invasive tests/surgical treatment in laboratories. Ref. 97/5277.

22. Andersen BM, Røed RT, Solheim N, Levy F, Kristoffersen K, Moløkken I. Air quality and microbiological contamination in operating theaters. Tidsskr Nor Legeforen. 1998;118:3148-51.

23. Andersen BM, Solheim N. Occlusive scrub suits in operating theaters during cataract surgery; effect on airborne contamination. Infect Control Hosp Epidemiol. 2002;23:218-20.

24. Andersen BM, Rasch M, Hochlin K, Jensen FH, Wismar P, Fredriksen JE. Decontamination of rooms, medical equipment and ambulances, using a dry mist of hydrogen peroxide disinfectant. J Hosp Infect. 2006;62:149-55.

25. Andersen BM, Hochlin K, Daling JP. Cleaning and decontamination of reusable medical equipments, including such the use of hydrogen peroxide dry-mist gas decontamination. $\mathrm{J}$ Microbiol Biochem Technol. 2012;4:57-62.

26. Andersen BM, Syversen G, Thoresen H, Rasch M, Hochlin K, Seljordslia B, Snevold I, Berg E. Failure of dry mist of hydrogen peroxide 5\% to kill Mycobacterium tuberculosis. J Hosp Infect. 2010;76:80-3. 
27. Bacher Christensen J, Andersen BM, Thomassen SM, Johansen O, Lie M. The effects of «in use» surgical handwashing on the pre- and postoperative fingertip flora during cardiothoracic and orthopedic surgery. J Hosp Infect. 1995;30:283-95.

28. Boyce JM, Pittet D. Guideline for hand hygiene in health care settings. CDC Morb Mort Wkly Rep. 2002;51:1-45.

29. Newman JB, Bullock M, Goyal R. Comparison of glove donning techniques for the likelihood of gown contamination. An infection control study. Acta Orthop Belg. 2007;73:765-71.

30. Jones C, Brooker B, Genon M. Comparison of open and closed staff assisted glove donning on the nature of surgical glove cuff contamination. ANZ J Surg. 2010;80:174-7.

31. Stacey A, Humphreys H. A UK historical perspective on operating theater ventilation. J Hosp Infect. 2002;52:77-80.

32. Tanner J, Parkinson H. Double gloving two reduce surgical cross-infection. Cochrane, 7 Oct 2009.

33. Hoborn J. Transmission or aerobic skin organisms via contact. In: Hoborn J, editor. Humans as dispersers of microorganisms - dispersion patterns and prevention (Thesis). Gothenburg, Sweden: University of Gothenburg; 1981. p. 65-85.

34. Chiu KY, Fung B, Lau SK, Ng KH, Chow SP. The use of double latex gloves during hip fracture operations. J Orthop Trauma. 1993;7:354-6.

35. Ødegård Hagen G, Arntzen H. Risk of perforation of surgical gloves. Tidsskr Nor Legeforen. 2007;127:856-8.

36. Reinhold M, Ranheim A, Hommelstad J. Occurrence of holes in surgical gloves in neurosurgery. Tidsskr Sykepleien Forskn, Dec 2008.

37. Furuhashi M, Miyamae T. Effect of preoperative hand scrubbing and influence of pinholes appearing in surgical rubber gloves during surgery. Bull Tokyo Dent Med Univ. 1979;26:73-80.

38. Dawson Bowling S, Smith J, Butt D, et al. Should outer surgical gloves be changed intraoperatively before orthopedic prosthesis implantation? J Hosp Infect. 2011;78:156-7.

39. Reichel M, Heisig P, Kampf G. Identification of variables for aerobic bacterial density at clinically relevant skin sites. J Hosp Infect. 2011;78:5-10.

40. Tammelin A, Domicel P, Hambreus A, Ståhle E. Dispersal of methicillin-resistant Staphylococcus epidermidis by staff in an operating suite for thoracic and cardiovascular surgery: relation to skin carriage and clothing. J Hosp Infect. 2000;44:119-26.

41. Owers KL, James E, Bannister GC. Source of bacterial shedding in laminar flow theaters. J Hosp Infect. 2004;58:230-2.

42. Anonymous. Guideline for surgical attire. In: Guidelines for perioperative practice. Denver, CO: AORN, Inc.; 2014.

43. Scheibel JH, Jensen I, Pedersen S. Bacterial contamination of air and surgical wounds during joint replacement operations. Comparison of two different types of staff clothing. J Hosp Infect. 1991;19:167-74.

44. Tammelin A, Ljungqvist B, Rein Muller B. Single-use surgical clothing system for reduction of airborne bacteria in the operating room. J Hosp Infect. 2013;84:245-7.

45. Humphreys H, Russel AJ, Marshall RJ, Ricketts VE, Reeves DS. The effect of surgical theater head-gear on air bacterial counts. J Hosp Infect. 1991;19:175-80.

46. Hubble MJ, Weale AE, Perez JV, et al. Clothing in laminar-flow operating theaters. J Hosp Infect. 1996;32:1-7.

47. Sanzen L, Calrsson ÅS, Walder M. Air contamination during total hip arthroplasty in an ultra clean air enclosure using different types of staff clothing. J Arthoplasty. 1990;5:127-31.

48. Whyte W, Hamblen DL, Kelly IG, Hambreus A, Laurell G. An investigation of occlusive polyester surgical clothing. J Hosp Infect. 1990;15:363-74.

49. Gordon RJ, Bannister GC, Bowker KE, Mason AC, Cheung LL, Eames R. Headwear in laminar flow operating theaters. J Hosp Infect. 2009:289-91.

50. Tammelin A, Ljungqvist B, Rein Muller B. Comparison of three distinct surgical clothing systems for protection from air-borne bacteria: a prospective observational study. Patient Saf Surg. 2012;6:23.

51. AORN Surgical attire policy. 2014. 
52. Meyer KK, Beck WC. Gown-glove interface: a possible solution to the danger zone. Infect Control Hosp Epidemiol. 1995;16:488-90.

53. Kong KC, Sheppard M, Serne G. Dispensing surgical gloves onto the open surgical gown pack does not increase the bacterial contamination rate. J Hosp Infect. 1994;26:293-6.

54. van der Reijden WA, Rood M, Vanderbroucke-Graul CMJE, de Soet JJ. Survival of bacteria on uniforms in relation to risk management in dental clinics. J Hosp Infect. 2009;73:283-5.

55. White A, Hoddinott C, Grant A. Blood contamination of the feet during orthopedic procedures. Ann R Coll Surg Engl. 1993;75:333-4.

56. Clesham K, Ryan P, Murphy C. Assessment of theatre shoe contamination in an orthopaedic theatre. J Hosp Infect. 2018;99:299-302.

57. Lipp A, Edwards P. Disposable surgical face masks for preventing surgical wound infection in clean surgery. Cochrane Database Syst Rev. 17 Feb 2014. The Cochrane Collaboration.

58. Mitchell NJ, Hunt S. Surgical face masks in modern operating rooms - a costly and unnecessary ritual? J Hosp Infect. 1991;18:239-42.

59. Phillips BJ, Fergusson S, Armstrong P, Anderson FM, Wildsmith JA. Surgical face masks are effective in reducing bacterial contamination caused by dispersal from the upper airway. BR J Anaesth. 1992;69:407-8.

60. McLure HA, Mannam M, Talboys CA, Azadian BS, Yentis SM. The effect of facial hair and sex on the dispersal of bacteria below a masked subject. Anesthesia. 2000;55:173-6.

61. Tarantola A, Abiteboul D, Rachline A. Infection risks following accidental exposure to blood or body fluids in health care workers: a review of pathogens transmitted in published cases. Am J Infect Control. 2006;34:367-75.

62. Berridge DC, Lees TA, Chamberlain J, Jones NA. Eye protection for the vascular surgeon. Br J Surg. 1993;80:1379-80.

63. McWilliams RG, Blanshard KS. The risk of blood splash contamination during angiography. Clin Radiol. 1994;49:59-60.

64. Kouri DL, Ernest JM. Incidence of perceived and actual face shield contamination during vaginal and cesarean delivery. Am J Obstet Gynecol. 1993;169:312-5.

65. Endo S, Kanemitsu K, Ishii H, et al. Risk of facial splash in four major surgical specialties in a multicenter study. J Hosp Infect. 2007;67:56-61.

66. Collins D, Rice J, Nicholson P, Barry K. Quantification of facial contamination with blood during orthopedic procedures. J Hosp Infect. 2000;45:73-5.

67. Jewett DL, Heinsohn P, Bennett C, Rosen A, Neuilly C. Blood-containing aerosols generated by surgical techniques: a possible infectious hazard. Am Ind Hyg Assoc J. 1992;53:228-31.

68. Bourouiba L, Dehanshoewerker E, Bush JWM. Violent expiratory events on coughing and sneezing. J Fluid Mech. 2014;845:537-63.

69. Aydin N, Esemenli T. Sweating: a formidable challenge in orthopedic surgery. J Hosp Infect. 2010;75:236-46.

70. Dumville JC, McFarlane E, Edwards P, Lipp A, Holmes A, Liu Z. Preoperative skin antiseptic for prevention of surgical wound infections after clean surgery. 21 Apr 2015. Cochrane.

71. Young HL, Reese S, Knepper B, Miller A, Mauffrey C. The effect of preoperative skin preparation products on surgical site infection. Infect Control Hosp Epidemiol. 2014;35:1535-8.

72. Anonymous. Guideline for preoperative patient skin antisepsis. AORN, 6 Nov 2014.

73. Johnston DH, Fairclough JA, Brown EM, Morris R. Rate of bacterial recolonization of the skin after preparation: four methods compared. Br J Surg. 1987;74:64.

74. Webster J, Alghamdi A. Use of plastic adhesive drapes during surgery for preventing surgical site infection. Cochrane, 22 Apr 2015.

75. Falk- Brynhildsen K, Söderquist B, Friberg E, Nilsson UG. Bacterial recolonization of the skin and wound contamination during cardiac surgery: a randomized controlled trial of the use of plastic adhesive drape compared with bare skin. J Hosp Infect. 2013;84:151-8.

76. Mohan HM, McDermott S, Fenelon L, et al. Plastic wound retractors as bacteriological barriers in gastrointestinal surgery: a prospective multi-institutional trial. J Hosp Infect. 2012;81:109-13. 
77. Au E, Gossage JA, Bailey SR. The reporting of needlestick injuries sustained in theater by surgeons: are we under-reporting? J Hosp Infect. 2008;70:66-70.

78. Raahave D. Operative precautions in HIV and other bloodborne virus diseases. Infect Control Hosp Epidemiol. 1996;17:529-31.

79. Perdelli F, Spagnolo AM, Cristina ML, et al. Evaluation of contamination by blood aerosols produced during various healthcare procedures. J Hosp Infect. 2008;70:174.

80. Andersen BM. Hepatitis and other bloodborne virus diseases. Handbook in hygiene and infection control in hospitals. Part 1. Microbiology and infection control. Fagbokforlaget. 2014. p. 167-205.

81. Lipscomb IP, Sihot AK, Keevil CW. Diathermy forceps and pencils: reservoirs for protein and prion contamination? J Hosp Infect. 2006;64:193-4.

82. Zamora N, Esteban J, Kinnari TJ, Celdran A, Granizo JJ, Zafra C. In-vitro evaluation of the adhesion to polypropylene sutures of non-pigmented, rapidly growing mycobacteria. Clin Microbiol Infect. 2007;13:902-7.

83. Scaltriti S, Cencetti S, Rovesti S, Marchesi I, Bargellini A, Borella P. Risk factors for particulate and microbial contamination of air in operating theaters. J Hosp Infect. 2007;66:320-6.

84. Griffiths P, Renz A, Hughes J, Rafferty AM. Impact of organization and management factors on infection control in hospitals: a scoping review. J Hosp Infect. 2009;73:1-14.

85. Gastmeier P, Söhren D, Breier A, Behnke M, Geffers C. Prolonged duration of operation: an indicator of complicated surgery or of surgical (mis) management? Infection. 2011;39:211.

86. DeLuca W. The challenges associated with loaner instrumentation. Healthcare departmentssterile processing. Infect Control, 19 Apr 2018.

87. Dandalides PC, Rutala WA, Sarubbi FA Jr. Postoperative infections following cardiac surgery: association with an environmental reservoir in a cardiothoracic intensive care unit. Infect Control. 1984;5:378-84.

88. Pitten FA, Panzer B, Schroder G, Tietze K, Kramer A. Transmission of a multiresistant Pseudomonas aeruginosa strain at a German university hospital. J Hosp Infect. 2001;47:125-30.

89. Teltsch DY, Hanley J, Loo V, et al. Infection acquisition following intensive care unit room privatization. Arch Intern Med. 2011;171:32-8.

90. Andersen BM, Lippe von der B, Lie M, Øgrey T. High-risk, infectious persons. How to isolate and treat in hospitals. Experience with multi-drug resistant tuberculosis. Toxic Trip Portugal, NATO, June 2001.

91. Øgrey T, Andersen BM. Multi-resistant tuberculosis operation. In: Handbook in hygiene and infection control in hospitals. 2008. p. 246-9.

92. Andersen BM. Mycobacteria. In: Handbook in hygiene and infection control in hospitals. Part 1. Microbiology and infection control. Fagbokforlaget. 2014. p. 135-140.

93. Andersen BM. Does "airborne" hydrogen peroxide kill Mycobacterium tuberculosis? J Hosp Infect. 2011;77:83-5. 